\title{
The response of two Icelandic glaciers to climatic warming computed with a degree-day glacier mass-balance model coupled to a dynamic glacier model
}

\author{
Tómas Jóhannesson* \\ Orkustofnun (National Energy Authority), Grensásvegi 9, IS-108 Reykjavik, Iceland
}

\begin{abstract}
A degree-day glacier mass-balance model is coupled to a dynamic glacier model for temperate glaciers. The model is calibrated for two outlet glaciers from the Hofsjökull ice cap in central Iceland. It is forced with a climate scenario that has recently been defined for the Nordic countries for the purpose of outlining the hydrological consequences of future greenhouse warming. The scenario for Iceland specifies a warming rate of $0.25^{\circ} \mathrm{C}$ per decade in mid-summer and $0.35^{\circ} \mathrm{C}$ per decade in mid-winter with a sinusoidal variation through the year. The volume of the glaciers is predicted to decrease by approximately $40 \%$ over the next century, and the glaciers essentially disappear during the next 200 years. Runoff from the area that is presently covered by the glaciers is predicted to increase by approximately $0.5 \mathrm{~m}^{-1} 30$ years from now due to the reduction in the volume of the glaciers. The runoff increase reaches a flat maximum of $1.5-2.0 \mathrm{~m} \mathrm{a}$ $100-150$ years from now and levels off after that. The predicted runoff increase leads to a significant increase in the discharge of rivers fed by meltwater from the outlet glaciers of the ice cap and may have important consequences for the operation and planning of hydroelectric power plants in Iceland.
\end{abstract}

\section{INTRODUGTION}

The mean surface air temperature of the Earth may rise by about $0.1-0.35^{\circ} \mathrm{C}$ per decade during the next decades due to increasing concentrations of $\mathrm{CO}_{2}$ and other greenhouse gases in the atmosphere (Houghton and others, 1990, 1992, 1996). If realised, this warming will cause worldwide glacier retreat and lead to major runoff changes in glaciated areas. Increased runoff from glaciated areas is important for future global sea-level rise that may occur as a consequence of future climate warming (Warrick and others, 1996). Glacier dynamics will play a significant role in determining the time-dependent evolution of future runoff changes in glaciated areas. Therefore it is important to study the interaction between predicted glacier mass-balance changes and glacier dynamics when future runoff changes from glaciated areas are analyzed.

The ratio of the rate of change of glacier volume to a small change in a climatic parameter, usually temperature, is termed the static sensitivity of glaciers to climate changes (Warrick and others, 1996). The static sensitivity ignores the effect of time-dependent retreat of the glacier terminus, changes in the geometry of the glacier, non-linear effects due to the finite size of the climate change and other dynamic and non-linear effects. Including these effects leads to the concept of dynamic sensitivity of glaciers to climate change. The contribution of glaciers and ice caps to global

Present affiliation: Vedurstofa Íslands (Icelandic Meteorological Office), Bústadavegi 9, IS-150 Reykjavík, Iceland. sea-level rise in the future is analyzed in two independent ways in Warrick and others (1996). An approach based on Wigley and Raper (1995) takes dynamic effects into account in a heuristic way, whereas an approach based on Oerlemans and Fortuin (1992) uses a range of static sensitivities of glaciers depending on latitude. The results of the two approaches differ considerably, but both nevertheless indicate an average near $0.5 \mathrm{~m}$ w.e. a ${ }^{-1} \mathrm{C}^{-1}$ for the global sensitivity of glacier mass balance to climate warming in the early part of the next century.

As part of the Nordic project, Climate Change and Energy Production (Sxlthun, 1992), a coupled dynamic/ mass-balance glacier model for temperate glaciers has been developed in order to estimate the effects of global warming on glacier mass balance and runoff from glaciated areas. A special version of the HBV hydrological runoff model has been applied to selected Nordic river basins in order to estimate the hydrological effects of global warming (Sxlthun and others, 1994a, b; HBV (Hydrologiska Byrän Vattenbalanssektionen) is the section at the Swedish Meteorological and Hydrological Institute where the model was initially developed). The Icelandic river basins chosen for this study are partly glaciated. In order to estimate the effect of the retreat and thinning of glaciers within the basins, the coupled dynamic/mass-balance glacier model was run for these glaciers, and simulated changes in the extension and the altitude distribution of the glaciers were used in the hydrological modelling. The primary motivation behind this work was to estimate the hydrological consequences of climate changes in partly glaciated watersheds in Iceland. The results are also relevant in a wider context due to the importance of glaciers and small ice caps for future sea-level 
rise as mentioned above, because they shed some light on the relation between the static and dynamic sensitivity for the glaciers in question.

The results of the glacier modelling for two of the Icelandic glaciers that were considered in this modelling effort are described in this paper. These are Blöndujökull/Kvíslajökull on the western side of the Hofsjökull ice cap, central Iceland, and an unnamed outlet glacier on the northern side of Hofsjökull, which has been called Illviðrajökull, at Orkustofnun (see Fig. 1). In each case, the glacier that was modelled was delimited by the water divides of the rivers that were being considered in the runoff modelling, i.c. the river Blanda in the case of Blöndujökull/Kvíslajökull and the river AustariJökulsá in the case of Illvidrajökull (see Fig. 1). The location of the water divides and the area distribution of the ice surface and subglacial bottom topography are taken from Björnsson (1988).

Glaciers in Iceland started retreating from their Little Ice Age maximum between 1850 and 1900 and the rate of retreat became quite rapid after 1930 . As the climate became cooler after 1960, the retreat of the glaciers slowed down and many glaciers started advancing, especially after 1970 (Thórarinsson, 1974; Björnsson, 1980). Since about 1985 the climate has become warmer and many glaciers have started retreating again. On average, around $50 \%$ of monitored non-surging glaciers in Iceland have been advancing and around 50\% have been retreating in the period 1970-90 (Jóhannesson and Sigurdsson, 1992). On the whole, glaciers in Iceland may therefore be expected to respond to future climate changes from an initial state which is relatively close to a steady-state condition (at least compared with the rapid retreat between 1930 and 1960), although the time period $1960-90$ is too short for the glaciers to fully adjust to the climate during this period.

\section{THE GLACIER MASS-BALANCE MODEL}

The dynamic glacier model is coupled to the degree-day mass-balance model, MBT (Mass Balance of Temperate glaciers; Jóhannesson and others, 1995b). This model computes glacier mass balance as a function of altitude based on observed temperature and precipitation at a meteorological station.

Meteorological data from the meteorological station Nautabú $\left(65^{\circ} 27^{\prime} \mathrm{N}, 19^{\circ} 22^{\prime} \mathrm{W}, 115 \mathrm{~m}\right.$ a.s.l.) were used in the mass-balance modelling for both glaciers. Data from the meteorological station Hveravellir were used in the modelling of the mass balance of Sátujökull in Jóhannesson and others (1995b). In the study described here, the meteorological station Nautabú was chosen in preference to Hveravellir. Hveravellir is situated in a sheltered location between the ice caps Langjökull and Hofsjökull, and Nautabú is believed to be more representative of the hydrological basins of the rivers which were considered in the hydrological modelling.

Precipitation and temperature at altitude $z$ on the glacier are computed assuming a linear precipitation and temperature variation with altitude.

$$
\begin{aligned}
& T(z)=T\left(z_{\mathrm{ref}_{\mathrm{T}}}\right)-g_{\mathrm{T}}\left(z-z_{\mathrm{ref}_{\mathrm{T}}}\right), \\
& P(z)=\left[1+g_{\mathrm{P}}\left(z-z_{\mathrm{ref}_{\mathrm{P}}}\right)\right] P\left(z_{\mathrm{ref}_{\mathrm{P}}}\right),
\end{aligned}
$$

where $z_{\text {ref }}$ is the elevation the meteorological station, $z_{\mathrm{ref}}$ is a reference elevation for the precipitation gradient on the glacier (see below), and $g_{\mathrm{T}}$ and $g_{\mathrm{P}}$ are the gradients of temperature and precipitation, respectively. The special version of the HBV hydrological model which was used in this study represents the variation of precipitation with altitude as a linear function in up to two elevation ranges. This feature was used to specify different precipitation gradients for the ice-free and glaciated parts of the watersheds, a relatively low gradient of $8 \%$ per $100 \mathrm{~m}$ for the ice-free highland areas and a higher gradient of $30-50 \%$ per $100 \mathrm{~m}$ (see Table 2 below) for the glaciated parts of the basins. The reference elevation for the precipitation gradient on the glacier is therefore higher than the elevation of the meteorological station. A precipitation correction with separate correction factors for rain and snow was applied to the precipitation data in order to compensate for the effect of wind on the precipitation measurements and to transfer the precipitation measured at the meteorological station to the watershed in question. The correction factor for rain was given a value of 1.1 and the correction factor for snow was 1.4 for Blanda and 1.5 for Austari-Jökulsá. Precipitation on the glacier is assumed to fall as snow if the temperature at the altitude in question is below a specified threshold (see Table 2 below).

Melting of snow and ice is computed from the number of positive degree-days (PDD), using different degree-day factors (amount of melting per PDD) for snow and ice. A statistical approach was used in the determination of the number of positive degree-days. Variation of temperature within the year was modelled as a sinusoidal function with superimposed statistical fluctuations which are assumed to be normally distributed with a standard deviation $\sigma$ (see Reeh

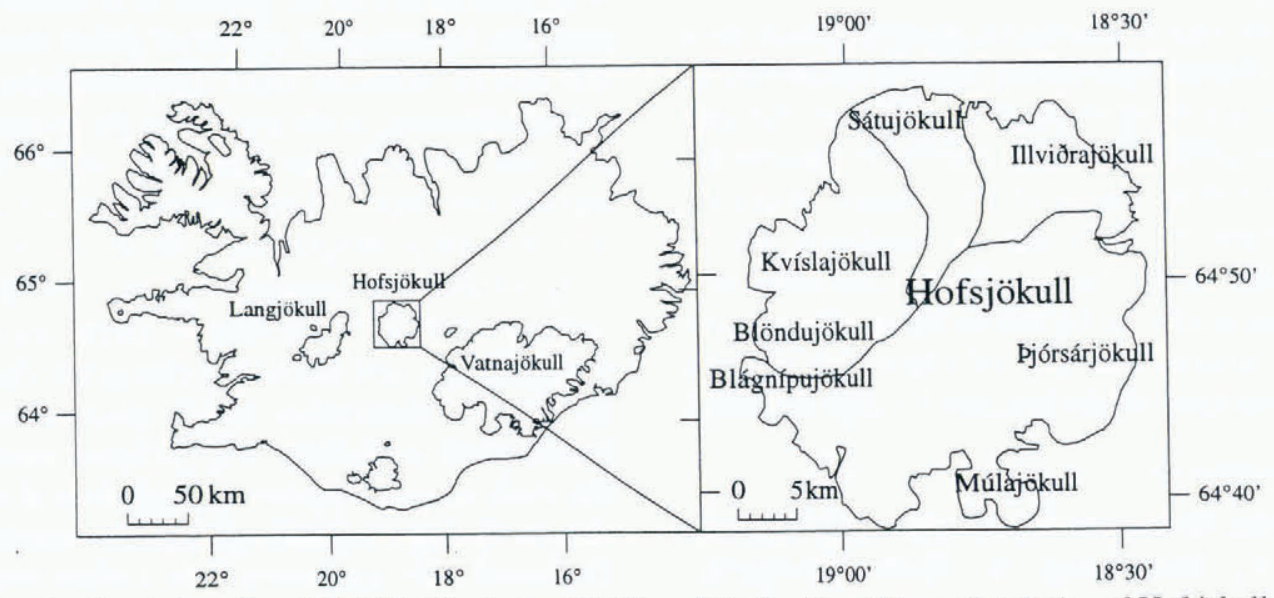

Fig. 1. Map showing the location of Hofsjökull in Iceland (left) and the location of the outlet glaciers of Hofsjökull (right). 
(1991) and Jóhannesson and others (1995b) for a more detailed description of this approach).

The sinusoidal temperature variation is given by

$$
T_{\mathrm{d}}(t)=T_{\mathrm{a}}+T_{\mathrm{co}} \cos \frac{2 \pi t}{A}+T_{\mathrm{si}} \sin \frac{2 \pi t}{A},
$$

where $t$ is time and $A$ is the length of a calendar year. The mean value and amplitude of the sinusoidal function were chosen to be $2.5^{\circ}$ and $7.1^{\circ} \mathrm{C}$, respectively, in accordance with measured yearly mean temperature and the July temperature at the Nautabú meteorological station in the period 1961-90. The statistically determined PDD is given by

$$
\mathrm{PDD}=\int_{0}^{A} \frac{1}{\sigma \sqrt{2 \pi}} \int_{0}^{\infty}\left(T-T_{\text {thresh }}\right) \mathrm{e}^{-\left[\dot{T}-T_{\mathrm{l}}(t)\right] 2 /\left(2 \sigma^{2}\right)} \mathrm{d} T \mathrm{~d} t,
$$

where $T$ is temperature at the elevation in question and $T_{\text {thresh }}$ is a threshold for the degree-day computations. The standard deviation of the statistical fluctuations was chosen to be $\sigma=3.3 \mathrm{C}$. The mass-balance model as described here computes the average variation of the glacier mass balance with elevation for the time period 1960-90. A detailed description of the mass-balance model is given in Johannesson and others (1995b).

The mass-balance model was calibrated by alternating runs of the HBV runoff model and the glacier mass-balance models as described by Einarsson and Johannesson (1994). Parameter adjustments were required in the hydrological model in order to produce better agreement with the hydrological discharge records in the rivers, so as to give modelled average variation of the glacier accumulation and ablation with elevation in agreement with available evidence about glacier accumulation and ablation. In each case a 7 year period of discharge measurements in the river was used for the calibration, and the rest of the available discharge data were used for verification. In this way, it was possible to derive model parameters which gave simulated glacier massbalance components in reasonable agreement with available glacier mass-balance observations (personal communication from O. Sigurdsson, 1994), and at the same time simulated runoff curves in agreement with observed runoff of the rivers fed by meltwater from the glaciers.

Scattered mass-balance measurements are available for Illviðrajökull, but only a few measurements are available from the upper part of the accumulation area of Blöndujökull/Kvislajökull, and no ablation measurements exist from this part of the Hofsjökull ice cap (personal communication from O. Sigurdsson, 1994). Mass-balance measurements have been performed on the neighbouring Sátujökull (see Fig. 1) since 1988 (Sigurdsson, 1989, 1991, 1993). The scattered mass-balance measurements from Illvidrajökull indicate that its mass-balance characteristics are similar to those of Sátujökull. The limited accumulation measurements on Blöndujökull/Kvislajökull indicate that there is less precipitation on this part of the ice cap than on the neighbouring Sátujökull, and runoff measurements in Blanda and Austari-Jökulsá indicate that ablation on this glacier is also somewhat lower than on Sátujökull at the same elevations. Based on these considerations, the degree-day coefficients for ice and snow for Illvidrajökull were chosen to be the same as previously determined by mass-balance modelling for Sátujökull by Jóhannesson and others (1995b). Degree-day coefficients for Blöndujökull/Kvíslajökull were chosen to be somewhat lower than for Sátujökull in order to produce glacier runoff in accordance with runoff meas- urements in Blanda. The temperature lapse rate for both glaciers was given a value of $0.6^{\circ} \mathrm{C}$ per $100 \mathrm{~m}$ which is slightly higher than used in Jóhannesson and others (1995b) for Sátujökull. A degree-day threshold of $-0.5^{\circ} \mathrm{C}$ (see the equation for PDD above) was used for the Blanda watershed in order to improve the seasonal variation of the runoff, but this has little effect on the glacier mass-balance modelling compared to a model with slightly higher degree-day coefficients and without a degree-day threshold. A degree-day threshold was not specified for the Austari-Jökulsá watershed. Tables 1 and 2 summarise the glacier mass-balance model parameters for the two glaciers.

\begin{tabular}{|c|c|c|c|}
\hline Parameler & Name & Value & Unit \\
\hline Elevation of temperature station & elt & 115 & ma.s.l. \\
\hline Elevation of precipitation station & elp & 115 & ma.s.l. \\
\hline Temperature lapse rate & grt & 0.6 & ${ }^{\circ} \mathrm{C}$ per $100 \mathrm{~m}$ \\
\hline Temperature standard deviation & sgm & 3.3 & $\mathrm{C}$ \\
\hline Snow/rain threshold & $\operatorname{tsn}$ & 1.0 & $\mathrm{C}$ \\
\hline $\begin{array}{l}\text { Snow thickness used in degree-day } \\
\text { computations }\end{array}$ & sis & 0.3 & mw.e. \\
\hline Refreezing ratio & $\mathrm{rfr}$ & 0.07 & 1 \\
\hline
\end{tabular}

$$
\begin{aligned}
& \text { Table 1. Station and mass-balance model parameters common } \\
& \text { to both glaciers ( see Jóhannesson and others (1995b) for } \\
& \text { further explanation) }
\end{aligned}
$$

Table 2. Mass-balance model parameters which are different

\begin{tabular}{|c|c|c|c|c|}
\hline \multirow[t]{2}{*}{ Parameler } & \multirow[t]{2}{*}{ Name } & \multicolumn{2}{|c|}{ Value } & \multirow[t]{2}{*}{ Unit } \\
\hline & & Blanda & Jöhulsá & \\
\hline Degrec-day factor for ice & ddi & 0.00495 & 0.00756 & mw.e. ${ }^{0} \mathrm{C}^{-1} \mathrm{~d}^{-1}$ \\
\hline Degree-day factor for snow & dds & 0.0045 & 0.0056 & mw.e. $C^{-1} \mathrm{~d}^{1}$ \\
\hline $\begin{array}{l}\text { Starting elevation for } \\
\text { precipitation gradient }\end{array}$ & elq & 900 & 990 & ma.s.l. \\
\hline Precipitation/elevation gradient & grp & 0.36 & 0.496 & 1 per $100 \mathrm{~m}$ \\
\hline
\end{tabular}
for the two glaciers (the column labelled "Blanda" applies to Blöndujökull/Kvislajökull, and the column labelled "Jökulsâ" to Illvidrajökull; see Jóhannesson and others (1995b) for further explanation)

The precipitation gradient on the glaciers was determined such that the glacier mass-balance model predicted the glacier to be in approximate equilibrium in the period 1961 -90. This is somewhat arbitrary of course, but the available evidence indicates that the glaciers were close to equilibrium in this period (personal communication from $\mathrm{O}$. Sigurdsson, 1994). The precipitation gradient determined in this way (see Table 2) led to modelled accumulation in relatively good agreement with the available accumulation measurements from the upper part of the accumulation areas of the glaciers and of the neighbouring Sátujökull. The glacier models thus start from an approximate steady state that is assumed to represent the climate of 1961-90, which is the climatological baseline chosen for the Climate Change and Energy Production project.

\section{THE DYNAMIC GLACIER MODEL}

The dynamic glacier model is a slightly modified version of 
the model described in Jóhannesson (1991). It describes the glacier as a one-dimensional flow system analogous to traditional models of valley glaciers flowing in valleys with variable width $w(x, h)$ (see Waddington, 1982). The model is based on the equation of continuity for ice, assuming a unique density of ice and a flux - geometry relationship which incorporates the flow law or the rheology of ice. The ice flow is described by the ice-volume-flux distribution $Q(x, t)$, which is related to ice thickness $h(x, t)$, channel crosssection area $A(x, t)$ and mass balance $B(x, t)$, through the one-dimensional continuity equation (Paterson, 1981),

$$
\frac{\partial A}{\partial t}+\frac{\partial Q}{\partial x}=B
$$

where $x$ denotes distance along the flow channel and $t$ denotes time.

For the two glaciers considered here, it is assumed that the ice thickness is only a function of the distance $x$ along the flow channel which implies that the width $w$ of the channel is independent of the ice thickness $h$. For this simple geometry, the flux-geometry relationship will be taken to be

$$
q \equiv \frac{Q}{w}=K\left(\frac{-\partial z_{\mathrm{s}}}{\partial x}\right)^{n} h^{n+2},
$$

where $z_{\mathrm{s}}$ is the altitude of the ice surface, $K=$ $2 A(\rho g)^{n} /(n+2), n=3, \rho=900 \mathrm{~kg} \mathrm{~m}^{-3}, g=9.82 \mathrm{~m} \mathrm{~s}^{-2}$, and $A=5.3 \times 10^{-24} \mathrm{~s}^{-1} \mathrm{~Pa}^{-3}$ is a constant in the flow law of ice (Paterson, 1994). Formally, this flux-geometry relationship ignores basal sliding, but as in Jóhannesson (1991) it will be assumed that sliding can be adequately taken into account by varying the constant $K$ in the above equation. In view of the uncertain values of the constants $A$ and $n$ in the flow law of ice (see Paterson, 1994) this is not a drastic simplification.

The numerical formulation of the model equations is based on the control-volume concept (Patankar, 1980). A time step $\Delta t=1$ year and a grid spacing $\Delta x=0.25 \mathrm{~km}$ in the interior of the glaciers and $\Delta x=0.1 \mathrm{~km}$ near the terminus were used in the numerical calculations.

The bedrock and ice surface of the datum model glaciers were determined from the area distributions of the subglacial bedrock and the ice surface for the corresponding watersheds of the Hofsjökull ice cap in the same way as described in Jóhannesson (1991). The width, $w(x)$, of the flow channels was estimated from recent maps of the Hofsjökull ice cap (Björnsson, 1988). Figure 1 shows the divides which were used in the delineation of the glaciers. This procedure provides one-dimensional flow-channel model glaciers with the same area distributions of the bedrock and ice surface as are observed for the glaciers under consideration. Due to the simplifying assumptions about the geometry of the glaciers, each outlet glacier is considered independent of other outlet glaciers from the same ice cap, and all transverse variations in the ice surface and bedrock geometry are ignored. Thus, the models are very crude representations of the real glaciers. However, one may expect that the simulated response of the model glaciers to climate changes will capture the main features of the response of the real glaciers to such changes, because the model glaciers have the same size and overall shape as the real glaciers and a fairly realistic massbalance distribution. One must keep in mind that the subdivision of the Hofsjökull ice cap into independent ice-flow basins in the manner attempted here is an approximation of the true dynamics of the ice cap, which must involve some interaction between the ice-flow basins. This becomes especially important if the modelling leads to substantial modifications in the volume of the glaciers, which in reality may be expected to alter the division of the ice cap into ice-flow basins. This should be borne in mind when the results of the transient model runs presented below are interpreted.

The coupled dynamic/mass-balance glacier model was run until it reached a steady state for the present climate as specified by the temperature and precipitation of Nautabú in 1961-90. The area distribution of the modelled steady state is compared with the measured area distribution in Figure 2. It is seen that the overall thickness and shape of the glaciers is adequately represented by the model, although there are slight discrepancies between the measured and modelled distributions in the upper part of the accumulation areas.

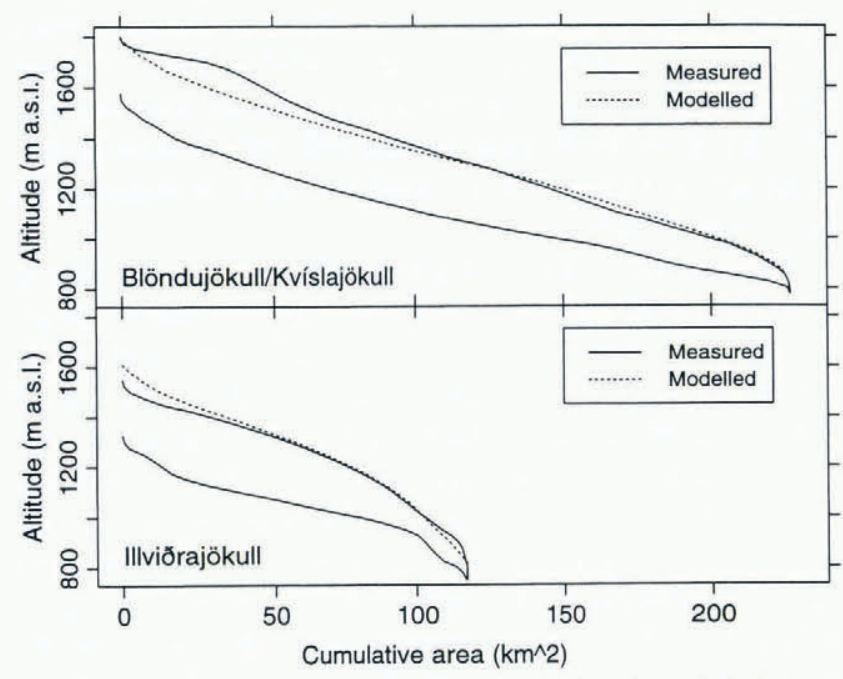

Fig. 2. Measured area distribution with elevation of the bedrock and ice surface (solid curves) for Blöndujökull) Kvislajökull (upperpanel) and Illvidrajökull (lower panel) together with the area distribution of the modelled steady-state ice surface corresponding to the climate of 1961-90 (dashed curve). The measured distributions are taken from Björnsson (1988).

\section{RESPONSE TIME}

The response time of a glacier can be defined as the time constant in an exponential asymptotic approach to a final steady state after a sudden change in climate to a new constant climate. Behind this definition lies the assumption that the time-dependent approach of a glacier to a new steady state after a small step change in climate will be relatively close to an exponential variation. It is of course possible to bypass this assumption of near-exponential variation by defining the response time as the time it takes the glacier volume perturbation to reach $\left(1-\mathrm{e}^{-1}\right)$ of its final steady-state value. This, however, eliminates only superficially the hidden assumption of a near-exponential variation, because a response time defined in this way would be of little value if the time-dependent response were in fact far from exponential. It is of interest to compute the time-dependent response of glaciers to small step changes in climate both for estimating the response time of the glaciers and also to compare the response to an exponential variation, i.e. $\Delta V=\Delta V_{\infty}$ $\left(1-\mathrm{e}^{-t / \tau}\right)$, where $\Delta V_{\infty}$ is the volume perturbation in the limit $t \rightarrow \infty$, and $\tau$ is the response time. 
The response time of the glaciers was estimated by suddenly increasing the temperature by $0.5^{\circ} \mathrm{C}$ and analyzing the approach of the glaciers to a new steady state. Figure 3 compares the computed approach to a new steady state with an exponential variation predicted for a linear reservoir with a response time of 100 years for Blöndujökull/Kvíslajökull and 60 years for Illvidrajökull. It is evident that the time-dependent approach to a new steady state is relatively close to an exponential variation. This conclusion is approximately valid for other temperature changes over a wide range of values until the steady-state volume change caused by the temperature change becomes on the order of one-half of the current volume of glaciers (not shown).

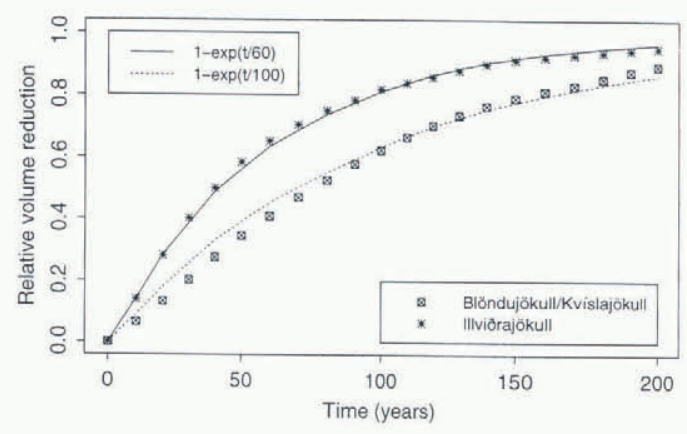

Fig. 3. Relative volume reduction as a function of time (symbols) following a sudden warming of $0.5^{\circ} \mathrm{C}$ compared with an exponential relaxation with a time-scale of 100 years for Blöndujökull/Kvislajökull and 60 years for Illvidrajökull (solid curves).

The estimated response times may be compared with the theoretical estimate $\tau=h_{0_{\max }} /\left(-b_{\mathrm{T}}\right)$ (see Jóhannesson and others, $1989 \mathrm{a}, \mathrm{b}$ ), where $h_{0_{\max }}$ is a scale for the (maximum) thickness of the glacier and $\left(-b_{\mathrm{T}}\right)$ is a scale for the mass balance near the terminus (more exactly the average mass balance on the region exposed by the retreat of the glacier or advanced over by an advancing glacier). For Blöndujökull/Kvislajökull this estimate is $\tau=93$ years $\left(h_{0_{\max }} \approx 250 \mathrm{~m}\right.$ and $\left.\left(-b_{\mathrm{T}}\right) \approx 2.7 \mathrm{ma}^{-1}\right)$, and for Illviorajökull $\tau=79$ years $\left(h_{0_{\max }} \approx 300 \mathrm{~m}\right.$ and $\left.\left(-b_{\mathrm{T}}\right) \approx 3.8 \mathrm{~m} \mathrm{a}^{-1}\right)$, if the mass balance around $900 \mathrm{~m}$ a.s.l. is used for estimating $\left(-b_{\mathrm{T}}\right)$. The theoretical estimate does not take the effect of variation in the width of the glacier with distance along the flow channel into account. As discussed in Jóhannesson and others (1989a), one may expect the response time of glaciers in widening flow channels to be somewhat shorter than that of glaciers of uniform width. The response time of a glacier in a linearly widening channel (or equivalently a cylindrically symmetrical ice cap) may be expected to be reduced by a factor of two-thirds compared to the response time of a glacier of uniform width. The width of Illvidrajökull increases approximately linearly with distance along the flow channel, whereas the width of Blöndujökull/Kvislajökull increases rapidly in the upper part of the accumulation area and relatively slowly in the lower part of the accumulation area and in the ablation area (see Fig. 1). Therefore, the above theoretical estimate of the response time of Blöndujökull/Kvíslajökull is appropriate, but the estimate for Illviorajokull should be reduced by a factor of the order of two-thirds to approximately 53 years in order to take the effect of the shape of the glacier into account. The theoretical estimates do not take mass-balance eleva- tion feedback into account and one may expect the true response time to be somewhat longer than the theoretical estimates due to this effect.

The numerically estimated response times of Blöndujökull/Kvíslajökull (100 years) and Illviðrajökull (60 years) are in reasonable agreement with the theoretical estimates when the effect of the variation of the channel width is accounted for as discussed above (93 years for Blöndujökull/Kvíslajökull and 53 years for Illviðrajökull) and the expected effect of mass-balance elevation feedback on the response time is kept in mind. Previous modelling of the entire Hofsjökull ice cap with a simpler numerical model indicated a response time of 50 years for the whole ice cap (Jóhannesson, 1991). The notion of different response times for different outlet glaciers and ice-flow basins of the same ice cap is of course only approximately valid. Nevertheless, the above results indicate that the response of the Hofsjökull ice cap and/or its individual ice-flow basins to moderate climate changes can be qualitatively modelled with a linear reservoir with a response time of 50-100 years and that this estimate of the response time can be derived theoretically from the current geometry and mass-balance characteristics of the ice cap.

\section{TRANSIENT RESPONSE TO CLIMATE CHANGES}

For Iccland, the climate scenarios used in the Climate Change and Energy Production project specify a warming rate of $0.25 \mathrm{C}$ per decade in mid-summer and $0.35^{\circ} \mathrm{C}$ per decade in mid-winter, with a sinusoidal variation through the year (Jóhannesson and others, 1995a). Precipitation is assumed to increase by $5 \%$ per ${ }^{\circ}$ of warming. These climate trends were superimposed on the average temperature and precipitation of the period 1961-90 in transient runs of the coupled dynamic/mass-balance glacier model.

The glacier models were run 200 years forward in time from a near-steady state at $t=0$. The retreat of the glaciers is shown in Figure 4. The reduction in the volume of the glaciers after 100 years is about $40 \%$ for each glacier, and

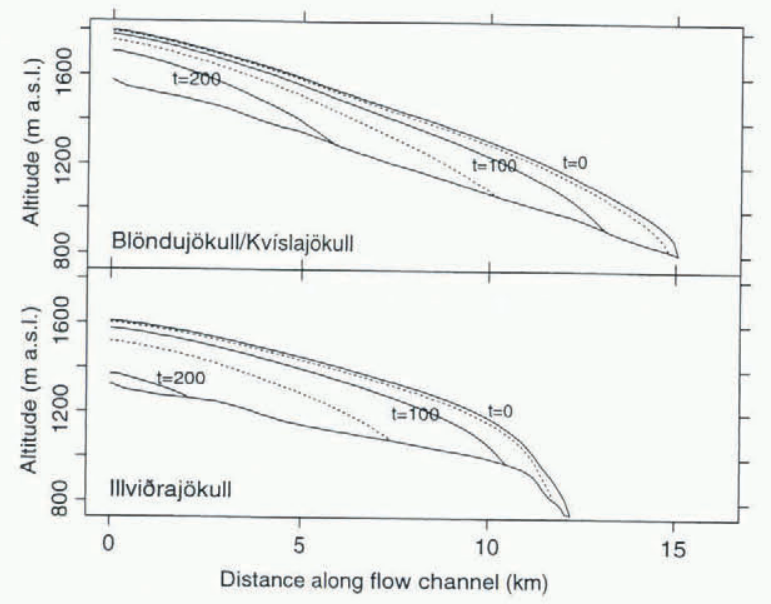

Fig. 4. Glacier profiles as a function of time for 200 years after the climate starts to warm for Blöndujökull/Kvislajökull (upper panel) and Illvidrajökull (lower panel). The outermost profile is the datum ice-surface profile at $t=0$, and the innermost profile is the ice surface at $t=200$. The time interval between the profiles is 50 years. The lowest profile in each panel is the glacier bed. 
the reduction in the ice-covered area is about $20 \%$ for Blöndujökull/Kvíslajökull and 25\% for Illvidrajökull at $t=$ 100. The glaciers essentially disappear at $t=200$, with less than $10 \%$ of the initial ice volume remaining.

The reduction in the volume of the glaciers leads to a substantial increase in glacier runoff. Figure 5 shows the variation of the ice volume of the glaciers with time, and the predicted runoff increase from the area presently covered by the glaciers. After 30 years the runoff contribution due to the negative net balance of the glaciers to the runoff from the area presently covered by the glaciers is $0.5 \mathrm{~m} \mathrm{a}^{-1}$ for Blöndujökull/Kvíslajökull and $0.6 \mathrm{~m} \mathrm{a}^{-1}$ for Illviðrajökull. This is approximately $25 \%$ of the present runoff from the glaciers. This runoff contribution increases approximately linearly to a maximum of about $1.5 \mathrm{~m} \mathrm{a}^{-1}$ for Blöndujökull/Kvíslajökull and $1.8 \mathrm{~m} \mathrm{a}^{-1}$ for Illviðrajökull $100-150$ years from now. This is close to $75 \%$ of the present runoff from the glaciers. The runoff starts to decrease after approximately 150 years due to the reduction in the ice-covered area, but it is still significantly above the present runoff at $t=200$. These results are in qualitative agreement with the previous results of Johannesson (1991) for the entire Hofsjökull ice cap which were based on a much simpler glacier mass-balance model.

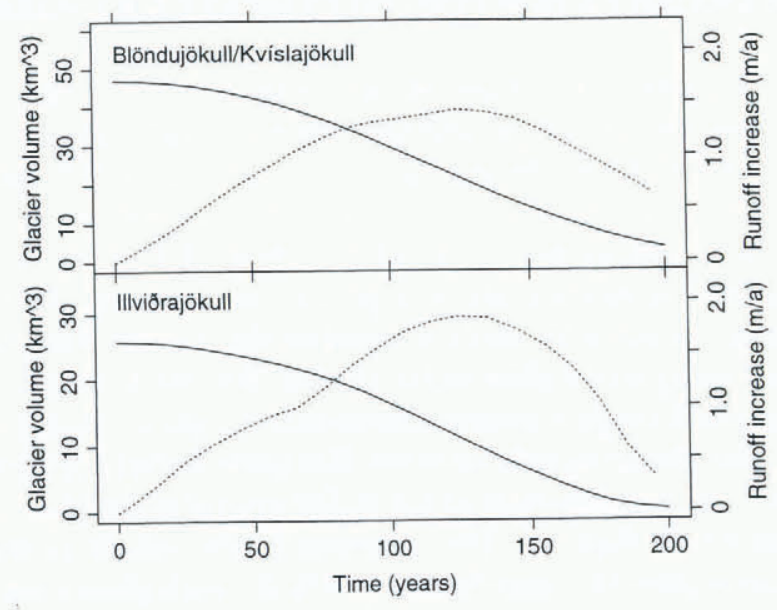

Fig. 5. Glacier volume as a function of time (solid curves) and predicted runoff increase from the area presently covered by the glaciers due to the reduction in the ice volume (dashed curves) for Blöndujökull/Kvislajökull (upper panel) and Illvidrajökull (lower panel).

\section{MASS-BALANCE SENSITIVITY}

The sensitivity of the mass balance of glaciers and ice caps to climate changes is important for future global sea-level rise that may occur as a consequence of climate warming as discussed in the introduction. The static sensitivity is typically defined as the ratio of the change of the area-weighted average of the specific mass balance over the altitude range of the glacier to the magnitude of a small temperature change. It does not take time-dependent changes in the geometry of the glacier into account. Although the static sensitivity is defined with respect to a small uniform change in temperature, it is useful to compute the change in specific mass balance as a consequence of a finite temperature change which may vary through the year with and without an accompanying precipitation increase. The results of such computations for Blöndujökull/Kvíslajökull and Illviðrajökull are shown in Tables 3 and 4. Most of the values in the tables are in the range -0.5 to $-1.0 \mathrm{~m}^{\circ} \mathrm{C}^{-1} \mathrm{a}^{-1}$. Seasonal variation and a precipitation reduce the sensitivity by approximately $0.1 \mathrm{~m}^{\circ} \mathrm{C}^{-1} \mathrm{a}^{-1}$ each, whereas the non-linear effect of the finite size of the warming increases the sensitivity by -0.1 to $-0.3 \mathrm{~m}^{\circ} \mathrm{C}^{-1} \mathrm{a}^{-1}$ for $\Delta T$ in the range $2-3 \mathrm{C}$ compared with a small $\Delta T$.

The dynamic sensitivity is computed directly from the volume reduction of the glacier as it responds to a time-

Table 3. Sensitivity of glacier mass balance for a uniform temperature increase with and without a $5 \%$ precipitation increase per ${ }^{\circ}$ Cof warming

\begin{tabular}{|c|c|c|c|c|}
\hline \multirow{3}{*}{$\begin{array}{r}\Delta T \\
{ }^{\circ} \mathrm{C}\end{array}$} & \multicolumn{2}{|c|}{ Blöndujökull/Kivislajökull } & \multicolumn{2}{|c|}{ Illvidrajökull } \\
\hline & $S_{\triangle P \neq 0}$ & $S_{\triangle P=0}$ & $S_{\triangle P \neq 0}$ & $S_{\Delta P=0}$ \\
\hline & $\mathrm{m} \mathrm{C}^{-1} \mathrm{a}^{-1}$ & $\mathrm{~m}^{\circ} \mathrm{C}^{-1} \mathrm{a}^{-1}$ & $\mathrm{~m}^{\circ} \mathrm{C}^{-1} \mathrm{a}^{1}$ & $\mathrm{~m}^{\circ} \mathrm{C}^{-1} \mathrm{a}^{-1}$ \\
\hline 0.1 & -0.5 & -0.6 & -0.7 & -0.8 \\
\hline 1.0 & -0.5 & -0.6 & -0.8 & -0.9 \\
\hline 2.0 & -0.6 & -0.7 & -0.9 & -1.0 \\
\hline 3.0 & -0.7 & -0.8 & -1.0 & -1.1 \\
\hline
\end{tabular}

Table 4. Sensitivity of glacier mass balance for a seasonal temperature increase where winter warming is $40 \%$ higher than summer warming with and without a $5 \%$ precipitation increase per ${ }^{\circ}$ Cof warming

\begin{tabular}{|c|c|c|c|c|}
\hline \multirow{3}{*}{$\begin{array}{r}\Delta T \\
\mathrm{C}\end{array}$} & \multicolumn{2}{|c|}{ Blöndujökull/Kviislajökull } & \multicolumn{2}{|c|}{ Illvidrajökull } \\
\hline & $S_{\triangle P \neq 0}$ & $S_{\triangle P=0}$ & $S_{\triangle P \neq 0}$ & $S_{\Delta P=0}$ \\
\hline & $\mathrm{m}^{\circ} \mathrm{C}^{-1} \mathrm{a}^{-1}$ & $\mathrm{~m}^{0} \mathrm{C}^{-1} \mathrm{a}^{-1}$ & $m^{0} \mathrm{C}^{-1} \mathrm{a}^{-1}$ & $\mathrm{~m}^{\circ} \mathrm{C}^{-1} \mathrm{a}^{-1}$ \\
\hline 0.1 & -0.4 & 0.5 & -0.6 & -0.7 \\
\hline 1.0 & -0.5 & -0.6 & -0.7 & -0.8 \\
\hline 2.0 & -0.5 & -0.6 & -0.8 & -0.9 \\
\hline 3.0 & -0.6 & -0.7 & 0.9 & -1.0 \\
\hline
\end{tabular}

dependent climate change. It therefore takes into account both the warming associated with the lowering of the ice surface and the retreat of the glacier terminus in addition to seasonal variation in the warming, a precipitation increase if present and the finite size of the warming which are described above. Here the dynamic sensitivity is computed as the total change in the volume of the glacier in the transient run described in the previous section divided by the original area of the glacier at the start of the integration and the average temperature change over the time interval. The dynamic sensitivities derived in this way for Blöndujökull/Kvíslajökull and Illvidrajökull are given in Table 5.

The dynamic sensitivity increases slightly with time during the first decades due to the lowering of the ice surface and reaches a fairly flat maximum around the time when the terminus starts retreating. The sensitivity does not start to fall off rapidly until after about 100 years. The fall is due to an accelerating retreat of the terminus. The dynamic lowering of the ice surface increases the sensitivity by less than $0.1 \mathrm{~m}^{\circ} \mathrm{C}^{-1} \mathrm{a}^{-1}$. For integrations longer than 100 years the lowering of the sensitivity due to the retreat of the terminus is substantial, and the sensitivity is reduced by about $50 \%$ for 200 year long integrations. 
Table 5. Dynamic sensitivity of glacier mass balance as a function of time from the start of the integration for a seasonal temperature change with a $5 \%$ precipitation increase per ${ }^{\circ} \mathrm{C}$ of warming

Time

\begin{tabular}{cc}
\multicolumn{2}{c}{ Sensitivity } \\
Blöndujökull/Kvislajökull & Illvidrajökull \\
$\mathrm{m} \mathrm{C}^{-1} \mathrm{a}^{-1}$ & $\mathrm{~m}^{\circ} \mathrm{C}^{-1} \mathrm{a}^{-1}$
\end{tabular}

years $\mathrm{m}^{0} \mathrm{C}^{-1} \mathrm{a}^{-1}$ $\mathrm{m}^{\circ} \mathrm{C}^{-1} \mathrm{a}^{-1}$

$\begin{array}{rrr}20 & -0.4 & -0.6 \\ 40 & -0.5 & -0.7 \\ 100 & -0.5 & -0.6 \\ 150 & -0.4 & -0.5 \\ 200 & -0.3 & -0.4\end{array}$

\section{CONGLUSIONS}

The modelling indicates that future climate warming of about $0.3^{\circ} \mathrm{C}$ per decade will have a dramatic effect on the two glaciers considered. The volume of the glaciers will be reduced by nearly $40 \%$ during the next century, and the runoff contribution from the diminishing ice storage will significantly increase the runoff in the rivers issuing from glaciers. The glaciers will essentially disappear during the next 200 years if the warming specified by the climate scenario continues unabated.

The response time of the glaciers estimated by numerical modelling is 50-100 years and can be derived theoretically from the current geometry and mass-balance characteristics of the glaciers. The dynamic response of the glaciers to moderate climate changes can be approximated by a linear reservoir with the appropriate response time. This indicates that the dynamic response of other temperate glaciers to climate changes can be estimated using a simple model based on a linear reservoir without performing detailed numerical ice-flow modelling of the glaciers.

The sensitivity of the mass balance of glaciers to a temperature increase is found to depend on the magnitude and seasonality of the warming, the presence of an accompanying precipitation increase and the dynamic lowering of the ice surface and the retreat of the terminus. These effects are partly counteractive and the dynamic sensitivity during the initial 100 years is not very different from the static sensitivity computed from the current geometry of the glaciers. After about 100 years the sensitivity is significantly reduced due to the decrease in the ice-covered area that results from the retreat of the glaciers.

\section{ACKNOWLEDGEMENTS}

This study was carried out as a part of Climate Change and Energy Production, a joint project between Denmark, Finland, Iceland, Norway and Sweden sponsored by the Nordic Council of Ministers. Data on the geometry of Hofsjökull were provided by H. Björnsson and F. Pálsson at the Science Institute, University of Iceland. Meteorological data were provided by the Icelandic Meteorological Office.

\section{REFERENCES}

Björnsson, H. 1980. Glaciers in Iceland. Jökull, 29, 1979, 7480.

Björnsson, H. 1988. Hydrology of ice caps in volcanic regions. Visindafëlag $\dot{I}_{s}$. Rit. 45.

Einarsson, K. and T. Jóhannesson. 1994. Correction of calibration biases in a runoff model for a partly glaciated river basin by the application of a glacier mass balance model. In Kern-Hansen, C,, D. Rosbjerg and R. Thomsen, eds. Norsk Hydrologisk Konferens 1994 (NHK-94). Copenhagen, Nordisk Hydrologisk Program, 589-595. (NHP-rapport 34.)

Houghton, J. T., G. J. Jenkins and J.J. Ephraums, eds. 1990. Climate change: the IPCC scientific assessment. Cambridge, etc., Cambridge University Press.

Houghton, J. T., B. A. Callander and S. K. Varney, eds. 1992. Climate change 1992: the supplementary reporl to the IPCC scientific assessment. Cambridge, etc., Cambridge University Press.

Houghton, J. T., L. G. Meiro Filho, B. A. Callander, N. Harris, A. Kattenberg and K. Maskell, eds. 1996. Climate change 1995: the science of climate change. Cambridge, etc, Cambridge University Press.

Johannesson, T. 1991. Modelling the effect of climate warming on the Hofsjökull ice cap, central Iceland. Nord. Hydrol., 22 (2), 81-94.

Jóhannesson, T. and O. Sigurdsson. 1992. Glacier hydrology in a changing climate. In Ostrem, G., ed. Nordic Hydrological Conference 1992, Alta, Norway, Aug. 4-6, 1992. Oslo, Nordic Association for Hydrology. Nordic Hydrological Programme, 683-692. (NHP-rapport 30.)

Jóhannesson, T., C. F. Raymond and E. D. Waddington. 1989a. A simple method for determining the response time of glaciers. In Oerlemans, J., ed. Glacier fluctuations and climatic change. Dordrecht, etc., Kluwer Academic Publishers, 343-352.

Jóhannesson, T., C. Raymond and E. D. Waddington. 1989b. Time-scale for adjustment of glaciers to changes in mass balance. J. Glaciol., 35 (121), $355-369$.

Jóhannesson, T., T. Jónsson, E. Källén and E. Kaas. 1995a. Climate change scenarios for the Nordic countries. Climatic Res., 5, 181-195.

Johannesson, T., O. Sigurdsson, T. Laumann and M. Kennett. 1995b. Degreeday glacier mass-balance modelling with applications to glaciers in Iceland, Norway and Greenland. F. Glaciol., 41 (138), 345-358.

Oerlemans, J. and J. P. F. Fortuin. 1992. Sensitivity of glaciers and small ice caps to greenhouse warming. Science, 258(5079), 115-117.

Patankar, S. V. 1980. Numerical heat transfer and fluid flow. New York, Hemisphere Publishing.

Paterson, W. S. B. 1994. The physics of glaciers. Third edition. Oxford, etc., Pergamon Press.

Reeh, N. 1991. Parameterization of melt rate and surface temperature on the Greenland ice sheet. Polarforschung, 59 (3), 1989, 113-128.

Salthun, N. R. 1992. Klimaendringer og energiproduksjon - en orientering. Vannet i Vorden, 25 (2), 8-12.

Salthun, N. R., K. Einarsson, G. Lindström, T. Thomsen and B. Vehviläinen. 1994a. Simulation of climate change impact on runoff in the Nordic countries. Part A. Model and catchments. In Kern-Hansen, C., D. Rosbjerg and R. Thomsen, eds. Norsk Hydrologisk Konferens 1994 (.NHK-94). Copenhagen, Nordisk Hydrologisk Program, 13-25. (NHP-rapport 34.)

Salthun, N. R., S. Bergström, K. Einarsson, T. Thomsen and B. Vehviläinen. 1994b. Simulation of climate change impact on runoff in the Nordic countries. Part B. Climate and runoff scenarios. In Kern-Hansen, C., D. Rosbjerg and R. Thomsen, eds. Norsk Hydrologisk Konferens 1994 (. HK-94). Copenhagen, Nordisk Hydrologisk Program, 3-12. (NHP-rapport 34.)

Sigurdsson, O. 1989. Afkoma Hofsjökuls 1987-1988. Reykjavík, Orkustofnun. Report OS-89005/VOD-02B.

Sigurosson, O. 1991. Afkoma Hofsjökuls 1988-1989. Reykjavik, Orkustofnun. (Report OS-91052/VOD-08B.

Sigurosson, O. 1993. Afkoma nokkurra jökla á Íslandi 1989-1992. Reykjavík, Orkustofnun. Report OS-93032/VOD-02.)

Thórarinsson, S. 1974. Sambúd lands og lýds í ellefu aldir. In Líndal, S., ed. Saga Íslands I. Reykjavík, Hid Íslenska Bókmentafëlag. Sögufélagid, $29-97$.

Waddington, E. D. 1982. Accurate modelling of glacier flow. (Ph.D. thesis, University of British Columbia.

Warrick, R. A., C. le Provost, M. F. Meier, J. Oerlemans and P. L. Woodworth. 1996. Changes in sea level. In Houghton, J. T., L. G. Meira Filho, B. A. Callander, N. Harris, A. Kattenberg and K. Maskell, eds. Climate change 1995: the science of climate change. Cambridge, New York, etc., Cambridge University Press, 359-405.

Wigley, T. M. L. and S. C. B. Raper. 1995. An heuristic model for sea level rise due to the melting of small glaciers. Geophys. Res. Lett., $22(20), 27492752$. 